\title{
RISK OF MALIGNANCY IN THE NON-DOMINANT THYROID NODULE
}

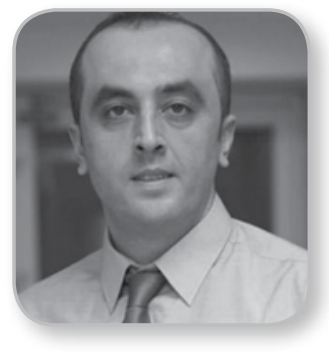

\author{
Varlik Erol $^{1}$, Özer Makay ${ }^{2}$, Yesim Ertan ${ }^{3}$, \\ Gokhan Icoz ${ }^{2}$, Mahir Akyildiz ${ }^{2}$ \\ ${ }^{1}$ Baskent University School of Medicine, Department of General \\ Surgery, Izmir, Turkey \\ ${ }^{2}$ Ege University School of Medicine, Department of General \\ Surgery, Izmir, Turkey \\ ${ }^{3}$ Ege University School of Medicine, Department of Pathology, \\ Izmir, Turkey
}

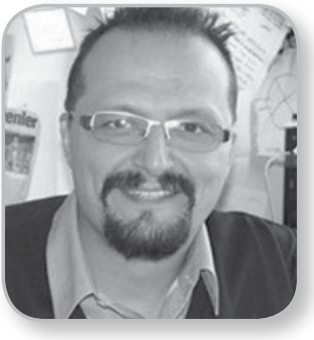

\section{INTRODUCTION}

In general, it is accepted that thyroid cancer is most often found in the dominant (largest) nodule in multinodular goiter. However, it is well-known that nearly one-third of the cases of cancer are found in non-dominant nodules [1]. The recommendation of biopsying the dominant nodule in a multinodular thyroid gland will result in missing the cancer diagnosis in these patients. Nodule size is a poor predictor for malignancy, as the likelihood of cancer has been shown to be the same regardless of nodule size [2]. Herein, we aimed to assess how frequently thyroid cancer is located in non-dominant nodules without the presence of malignancy in the dominant nodule and to determine optimal clinical management of those nondominant thyroid nodules.

\section{MATERIALS AND METHODS}

One hundred eleven consecutive patients (from 16 to 80 years old, mean age: $48 \pm 12$; females 91 and males 20 ) with a multinodular thyroid tissue and preoperatively or postoperatively diagnosed with thyroid cancer, entered the study. All patients were followed-up elsewhere for multinodular goiter. Cases were selected from 595 patients referred or individually applied to our endocrine surgery unit who underwent thyroid surgery. Thyroid cancer patients who underwent their initial surgery elsewhere and cases with a solitary nodule were excluded from the study.

All neck ultrasounds had been performed before the admission. Meanwhile, information regarding thyroid parenchyma (homogeneous, nonhomogeneous, with multiple lesions); thyroid volume; nodule echogenicity (hyper, iso- or hypoechoic); nodule echo structure (solid, mixed, or cystic); nodule margins (well defined, irregular, or blurred); presence of hyperechoic spots (coarse calcifications or microcalcifications); and finally nodular vascularity pattern was in common. After assessment with the ultrasound, fine needle aspiration biopsy (FNA) under ultrasound guidance was carried out. FNA findings were graded as benign, malignant, suspicious (indeterminate) or inadequate. Samples showing cellular atypia or suggestive of follicular lesions were included in the suspicious (indeterminate) category. If the FNA showed malignancy it did not divide papillary or follicular cancer.

Preoperative thyroid hormone assessment and indirect laryngoscopy were performed on all patients before operative intervention. Our routine operative strategy for multinodular disease is to perform a neartotal thyroidectomy (leaving less than $2 \mathrm{~g}$ of tissue if necessary to preserve parathyroid tissue or protect the recurrent laryngeal nerve) or a total thyroidectomy based on the results of preoperative tests, intraoperative exploration and frozen section analysis. Both lobes and the isthmus were carefully evaluated for the presence of any gross disease.

Data were expressed as the mean \pm standart deviation. Sensitivity for malignancy of different ultrasonographic features was calculated as the proportion of patients with positive ultrasound results among all patients with malignancy (the sum of true-positive and falsenegative results) on final histological examination.

\section{RESULTS}

All 111 patients in this study were confirmed to have malignancy based on final pathology. Of the 485 nodules included in the study, all were embedded 
in a multinodular tissue. A total of $52(47 \%)$ patients underwent FNA before surgery. Cytological evaluation of dominant nodules, which was carried out in 27 patients, revealed a suspicious result in $46 \%$ and malignancy in 19\%. FNA from non-dominant nodules was carried out in only 25 patients. Cytological evaluation of this sub-group revealed a suspicious result in $47 \%$ and malignancy in $24 \%$. False negative FNA results for the main and sub-group were calculated as $31 \%$ and $28 \%$, respectively. The overall distribution of final hystological diagnosis was papillary cancer in $93 \%$, follicular in $2.7 \%$, medullary in $2.7 \%$ and else in $1.6 \%$. Multifocal malignancies were observed in 64 (58\%) of 111 cases. Cytological diagnosis of multifocality was obtained preoperatively in none of our patients.

Mean dominant nodule size was $2.1 \pm 1.3 \mathrm{~cm}$, while mean malignant tumor size was $1.4 \pm 1.4 \mathrm{~cm}$ (range 0.1 to $7 \mathrm{~cm}$ ). Mean size of the non-dominant malignant nodules was $0.55 \pm 0.54 \mathrm{~cm}$ (range 0.1 to $3.2 \mathrm{~cm}$ ). Nodules under $10 \mathrm{~mm}$ in diameter represented $80 \%$ of the non-dominant malignant nodules.

Carcinomas were located in the dominant nodule in $61(55 \%)$ cases, while it was present in the nondominant nodules - without a neoplastic focus in the dominant nodule - in 50 (45\%) cases. In 20 (18\%) cases the carcinoma was found in both the dominant and the non-dominant nodule.

The ultrasound features of dominant and nondominant nodules are summarized in Table 1, in detail. It was observed that $18 \%$ of patients had ultrasound features associated with thyroid cancer in the nondominant nodule, while having benign characteristics in the dominant nodule. Sensitivities for malignancy of

Table 1

Ultrasound features of malignant non-dominant nodules

\begin{tabular}{|c|c|}
\hline Size (cm) & $0.55 \pm 0.54$ \\
\hline Solid nodule (\%) & 65 \\
\hline Microcalcification (\%) & 34 \\
\hline Hypoechogenicity (\%) & 76 \\
\hline Irregular margins (\%) & 34 \\
\hline Multifocality (\%) & 58 \\
\hline
\end{tabular}

the different ultrasonographic features are summarized in Table 2.

\section{DISCUSSION}

The purpose of the current study was to assess the prevalence of malignancy in dominant vs. nondominant lesions within multinodular goiters.

It is widely believed and accepted that thyroid carcinoma clinically presents as a solitary or dominant nodule in the majority of cases [3]. Twothirds of cancers found are localized to the dominant nodule with the remaining cancers localized to the nondominant nodule. Liebeskind et al. found that thyroid nodules discovered incidentally by ultrasound had a significantly higher risk of malignancy than those that were nonincidental ( $17 \%$ vs. $3 \% ; p=0.20)$ [4].

An increase in thyroid cancer incidence has recently been reported for different regions [5, 6]. However, most of these increases in thyroid cancer incidences were due to an increased detection of small papillary cancers. The increasing incidence of cancer in thyroid nodules requires evidence-based rational strategies for their differential diagnosis, risk stratification, treatment, and follow-up.

There are large discrepancies in the diagnosis and management of thyroid nodules between society sponsored guidelines published by the the American Association of Clinical Endocrinologists/Associazione Medici Endocrinologi (AACE/AME); the American Thyroid Association (ATA); and the European Thyroid Association (ETA) in 2006 [7, 8, 9]. The AACE/AME guidelines suggest a thyroid ultrasound for any patient with a palpable nodule, history of neck radiation, family history of thyroid cancer, or the presence of unexplai-

Table 2

Sensitivity of ultrasound features associated with thyroid cancer

\begin{tabular}{|c|c|}
\hline US feature & Sensitivity (\%) \\
\hline Solid nodule (\%) & 68 \\
\hline Microcalcification (\%) & 28 \\
\hline Hypoechogenicity (\%) & 69 \\
\hline Irregular margins (\%) & 43 \\
\hline Intranodule vascularity & 56 \\
\hline
\end{tabular}


ned cervical adenopathy. The ATA guidelines suggest that thyroid ultrasound should be performed in all patients with one or more suspected thyroid nodules. The ETA guidelines state that thyroid ultrasound is mandatory when a nodule is discovered at palpation [10].

Recently, the considerable controversy over whether clinically unapparent thyroid nodules should be assessed by FNA has not reached to a conclusion [11]. Meanwhile, several recent reports have suggested that ultrasound guided FNA is more reliable than palpationFNA [12]. With the use of ultrasound guidance, the sensitivity, positive and negative predictive values of FNA increase significantly. AACE/AME guidelines suggest ultrasound guided FNA for any size nodule with a history of radiation, or family history of RET; any size nodule with suspicious ultrasound features; for nodules with extra capsular growth or cervical nodes; and impalpable or small $(<1 \mathrm{~cm})$ nodules.

There are prospective studies that address the systematic evaluation of thyroid nodules discovered incidentally during ultrasonographic evaluation $[2,13$, $14]$.

Meanwhile, it is speculated that a rigorous approach to nodules smaller than $10 \mathrm{~mm}$ has not been shown to increase survival, and routine FNA of these nodules would not only be a huge burden for healthcare providers, but would also lead to a substantial number of unnecessary surgeries in patients with false-positive FNA results [15].

Microcancers (<10 $\mathrm{mm}$ in diameter) are frequently associated with benign thyroid pathologies, such as multinodular goiter [16]. Mostly, in these cases, the microcancer is diagnosed during pathologic evaluation of the extracted tissue, rather than during ultrasonographic evaluation. Due to improvements of the ultrasound, including wide application and availability for the evaluation of thyroid lesions and the use of FNA under ultrasonographic guidance, microcancers are diagnosed with an increased frequency. Incidental foci of microcarcinomas were found in a large percentage of patients after thyroidectomy for benign thyroid disease, ranging from $2 \%$ to $24 \%[17,18]$.

In a retrospective observational cohort study conducted between 1995 and 2003, Frates et al [1] assessed the prevalence, distribution, and sonographic features of thyroid cancer in patients with solitary and numerous thyroid nodules. The prevalence of thyroid cancer was similar among patients with a solitary nodule and patients with numerous nodules. In patients with numerous nodules greater than $10 \mathrm{~mm}$ in diameter, cancer was multifocal in $46 \%$ of patients, and $72 \%$ of cancers occurred in the largest nodule.

Nodule size is not predictive of malignancy, because the likelihood of cancer in a thyroid nodule has been shown to be the same regardless of the size measured at ultrasound $[2,19]$. Ultrasound features are helpful in determining the risk of cancer in a given nodule, but the high sensitivity of thyroid ultrasonography often detects small nodules of indeterminate clinical significance [20].

Recently, it is estimated that papillary microcancers account for up to $30 \%$ of all papillary cancers [21].

Pitfalls of our study: 1) ultrasound was not performed by one determined experienced radiologist but more 2) not all patients underwent FNA.

While thyroid cancers found in patients with multiple nodules are often located in the dominant nodule, in approximately one-third of cases the cancer is in a nondominant nodule [22]. This will result in undetected thyroid cancers in 33\% of cases if the radiologist and/ or endocrinologist focus on the dominant nodule. The data of our study, suggesting a higher incidence of cancer in the non-dominant thyroid nodule compared to the current literature, may simply be attributable to increased radiological and/or pathological detection of microcancers in the thyroid tissue evaluated or removed for another pathology, as previously mentioned by Grodski et al [23]. Another reason for high malignancy rate in the non-dominant nodule in our study might result from the selective use of ultrasound-guided FNA according to specific findings in multinodular goiter. However, there are reports suggesting no significant difference in the malignancy rate of patients with a solitary nodule and patients with multinodular disease $[24,25]$.

To define recommendations based on nodule size and ultrasonographic features, a consensus statement was attempted by the Society of Radiologists in Ultrasound with a panel of specialists from a variety of medical disciplines. According to this statement, regarding the selection of nodules for FNA, this should be based primarily on ultrasound characteristics other than nodule size [22]. Other two consensus statements (AACE/AME and ATA) agree with this [26].

\section{CONCLUSIONS}

The question regarding whether clinically unapparent non-dominant thyroid lesions in the multinodular goiter patient should be assessed should be no matter of debate. We advice all nodules to be evaluated 
routinely during ultrasonography and to perform an ultrasound-guided FNA in all incidentally discovered thyroid nodules with suspicious ultrasound findings.

\section{REFERENCES}

1. Frates $M C$, Benson $C B$, Doubilet $P M$, et al. Prevalence and distribution of carcinoma in patients with solitary and multiple thyroid nodules on sonography. J Clin Endocrinol Metab. 2006;91:3411-3417.

2. Papini E, Guglielmi $R$, Bianchini $A$, et al. Risk of malignancy in nonpalpable thyroid nodules: predictive value of ultrasound and color-Doppler features. J Clin Endocrinol Metab. 2002;87(5):19411946.

3. Polyzos SA, Kita M, Avramidis A. Thyroid nodules stepwise diagnosis and management. Hormones. 2007;6:101-119.

4. Liebeskind A, Sikora AG, Komisar A, Slavit D, Fried $K$. Rates of malignancy in incidentally discovered thyroid nodules evaluated with sonography and fine-needle aspiration. J Ultrasound Med. 2005;24:629.634.

5. Davies L, Welch HG. Increasing incidence of thyroid cancer in the United States, 1973-2002. Journal of the American Medical Association. 2006;295:21642167.

6. Colonna $M$, Guizard $A V$, Schvartz $C$, et al. A time trend analysis of papillary and follicular cancers as a function of tumour size: a study of data from six cancer registries in France (1983-2000). European Journal of Cancer. 2007;43:891-900.

7. Gharib H, Papini E, Valcavi R, Baskin HJ, Crescenzi A, Dottorini ME, Duick DS, Guglielmi R, Hamilton $C R \mathrm{Jr}$, Zeiger MA, Zini $M$; AACE/AME Task Force on Thyroid Nodules. American Association of Clinical Endocrinologists and Associazione Medici. Endocrinologi Medical Guidelines for Clinical Practice for the Diagnosis and Management of Thyroid Nodules. Endocrine Practice. 2006;12:63102.

8. Cooper DS, Doherty GM, Haugen BR, Kloos RT, Lee $S L$, Mandel SJ, Mazzaferri EL, Mclver B, Sherman SI, Tuttle RM; American Thyroid Association Guidelines Taskforce. Management guidelines for patients with thyroid nodules and differentiated thyroid cancer. Thyroid. 2006;16:109-142.

9. Pacini F, Schlumberger M, Dralle H, Elisei R, Smit JW, Wiersinga W; European Thyroid Cancer Taskforce. European Consensus for the management of patients with differentiated thyroid carcinoma of the follicular epithelium. European Journal of
Endocrinology. 2006;154:787-803.

10.Gharib H, Papini E, Paschke R. Thyroid nodules: a review of current guidelines, practices, and prospects. Eur J Endocrinol. 2008;159(5):493-505.

11. Giuffrida $D$, Gharib $H$. Controversies in the management of cold, hot, and occult thyroid nodules. Am J Med. 1995;99(6):642-650.

12.Gharib $H$, Papini E. Thyroid nodules: clinical importance, assessment, and treatment. Endocrinol Metab Clin North Am. 2007;36(3):707-735.

13.Hagag $P$, Strauss $S$, Weiss M. Role of ultrasoundguided fine-needle aspiration biopsy in evaluation of nonpalpable thyroid nodules. Thyroid. 1998;8(11):989-995.

14.Leenhardt L, Hejblum G, Franc B, Fediaevsky LDP, Delbot T, Guillouzic DL, Ménégaux F, Guillausseau $C$, Hoang C, Turpin $G$, Aurengo A. Indications and Limits of Ultrasound-Guided Cytology in the Management of Nonpalpable Thyroid Nodules. J Clin Endocrinol Metab. 1999;84(1):24-28.

15.Sakorafas GH, Giotakis J, Stafyla V. Papillary thyroid microcarcinoma: a surgical perspective. Cancer Treat Rev. 2005;31(6):423-38.

16. Yamamoto $Y$, Maeda $T$, Izumi $K$, Otsuka $H$. Occult papillary carcinoma of the thyroid. A study of 408 autopsy cases. Cancer. 1990;65(5):1173-1179.

17.Yamashita H, Nakayama I, Noguchi S, et al. Minute carcinoma of the thyroid and its development to advanced carcinoma. Acta Pathol Jpn. 1985;35(2):377-383.

18.Pelizzo MR, Piotto A, Rubello D, et al. High prevalence of occult papillary thyroid carcinoma in a surgical series for benign thyroid disease. Tumori. 1990;76:255-257.

19. Kim EK, Park CS, Chung WY, et al. New sonographic criteria for recommending fine-needle aspiration biopsy of nonpalpable solid nodules of the thyroid. AJR Am J Roentgenol. 2002;178(3):687-691.

20.Dean DS, Gharib H. Epidemiology of thyroid nodules. Best Pract Res Clin Endocrinol Metab. 2008;22(6):901-911.

21.Ito $Y$, Uruno $T$, Nakano $K$, et al. An observation trial without surgical treatment in patients with papillary microcarcinoma of the thyroid. Thyroid. 2003;13(4):381-387.

22.Frates $M C$, Benson $C B$, Charboneau JW, et al. Management of thyroid nodules detected at US: Society of Radiologists in Ultrasound consensus conference statement. Ultrasound Q.2006;22(4):231238.

23.Grodski S, Brown T, Sidhu S, et al. Increasing incidence 
of thyroid cancer is due to increased pathologic detection. Surgery 2008;144(6):1038-1043.

24.Nam-Goong IS, Kim HY, Gong $G$, et al. Ultrasonography-guided fine-needle aspiration of thyroid incidentaloma: correlation with pathological findings. Clin Endocrinol. 2004;60:21-28.

25. Frates MC, Benson CB, Doubilet PM, et al. Prevalence and distribution of carcinoma in patients with solitary and multiple thyroid nodules on sonography. J Clin Endocrinol Metab. 2006;91(9):3411-3417.

26. Morris LF, Ragavendra N, Yeh MW. Evidence-based assessment of the role of ultrasonography in the management of benign thyroid nodules. World J Surg 2008;32(7):1253-1263.

\section{SUMMARY}

Risk of malignancy in the non-dominant thyroid nodule

\section{Erol, Ö. Makay, Y. Ertan, G. Icoz, M. Akyildiz}

Purpose. The purpose of this study was to assess how frequently thyroid cancer is located only in the non-dominant nodules.

Methods. A total of 111 thyroid patients, whose primary operation were carried out at our institute and were confirmed to have thyroid cancer, were evaluated. Tumor characteristics were recorded in a retrospective database. Variables analyzed included patients' age and sex, nodule and tumor size, ultrasound features of nodules, fine needle aspiration biopsy result and the presence of multifocality of malignancy.

Results. There were 91 females and 20 males. Mean age was $48 \pm 12$ years (range $16-80$ years). Mean dominant nodule size was $2.1 \pm 1.3 \mathrm{~cm}$, while mean malignant tumor size was $1.4 \pm 1.4 \mathrm{~cm}$ (range $0.1-7 \mathrm{~cm}$ ). Carcinomas were located in the dominant nodule in 61 $(55 \%)$ cases, while it was present in the non-dominant nodules - without a neoplastic focus in the dominant nodule - in $50(45 \%)$ cases. In $20(18 \%)$ cases the carcinoma was found in both the dominant and the non-dominant nodule. Multifocality of the malignant tumor was present in 64/111 (58\%) cases.

Conclusions. Risk of malignancy in the non-dominant thyroid nodule should be kept in mind before carrying out a biopsy from the dominant nodule. Assessment of multinodular goiter should not be restricted to the dominant nodule.

Key words: thyroid cancer, multinodular goiter

\section{PEЗЮME}

\section{Ризик злоякісного процесу в недомінантному вузлі щитоподібної залози}

\section{Erol, Ö. Makay, Y. Ertan, G. Icoz, M. Akyildiz}

Мета. Метою нашого дослідження було оцінити, як часто рак щитоподібної залози локалізується лише у недомінантних вузлах.

Методи. Було обстежено 111 пацієнтів, яких первинно оперували в нашому закладі і в яких було підтверджено діагноз раку щитоподібної залози. Характеристики пухлин аналізували за записами в ретроспективній базі даних.

До аналізу включали дані про вік та стать хворих, розміри вузлів та пухлин, ультразвукові характеристики вузлів, результати тонкоголкової аспіраційної біопсії, наявність мультифокальності злоякісного процесу.

Результати. Жінок було 91, чоловіків 20. Середній вік пацієнтів становив $48 \pm 12$ років (від 16 до 80 років). Середній розмір домінантного вузла $2,1 \pm 1,3 \mathrm{~cm}$, середній розмір злоякісноїпухлини 1,4 41,4 см (від 0,1 до 9 см). Карциноми локалізувалися в домінантному вузлі в 61 (55\%) випадку, а в недомінантних вузлах (без неопластичного фокусу в домінантному вузлі) у 50 (45\%) випадках. У 20 (18\%) випадках карциноми було виявлено і в домінантному, і в недомінантних вузлах. Мультифокальність злоякісної пухлини була присутня у 64 зі 111 (58\%) випадків.

Висновки. Ризик злоякісного процесу в недомінантному вузлі слід враховувати перед проведенням біопсії домінантного вузла. Об'єм обстеження при багатовузловому зобі не слід обмежувати лише домінантним вузлом.

Ключові слова: рак щитоподібної залози, багатовузловий зоб.

\section{PEЗЮME}

\section{Риск злокачественного процесса В недоми- нантном узле щитовидной железы \\ V. Erol, Ö. Makay, Y. Ertan, G. Icoz, M. Akyildiz}

Цель. Целью нашего исследования было оценить, как часто рак щитовидной железы локализуется только в недоминантных узлах.

Методы. Обследовано 111 пациентов, которых первично оперировали в нашем учреждении и у которых был подтвержден диагноз рака щитовидной железы. Характеристики опухолей анализировали по записям в ретроспективной базе данных. В анализ включали данные о возрасте 
и поле больных, размерах узлов и опухолей, ультразвуковые характеристики узлов, результаты тонкоигольной аспирационной биопсии, наличие мультифокальности злокачественного процесса.

Результаты. Женщин было 91, мужчин 20. Средний

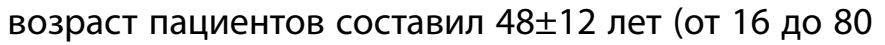
лет). Средний размер доминантного узла 2,1土1,3 см,

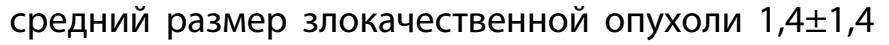
см (от 0,1 до 9 см). Карциномы локализовались в доминантном узле в 61 (55\%) случаев, а в недоминантных узлах (без неопластического фокуса в доминантном узле) - в 50 (45\%) случаев.
В 20 случаях (18\%) карциномы были обнаружены и в доминантном, и в недоминантных узлах. Мультифокальность злокачественной опухоли присутствовала в 64 из 111 (58\%) случаев.

Выводы. Риск злокачественного процесса в недоминантном узле следует иметь в виду перед проведением биопсии доминантного узла. Объем обследования при многоузловом зобе не следует ограничивать только доминантным узлом.

Ключевые слова: рак щитовидной железы, многоузловой зоб. 